\title{
Pregnant Uterus
}

National Cancer Institute

\section{Source}

National Cancer Institute. Pregnant Uterus. NCI Thesaurus. Code C12406.

A uterus containing one or more viable embryos or fetuses. 